\title{
Efficiency of soil and water conservation practices in different agro-ecological environments in the Upper Blue Nile Basin of Ethiopia
}

\author{
Dagnenet SULTAN ${ }^{1,2^{*}}$, Atsushi TSUNEKAWA ${ }^{3}$, Nigussie HAREGEWEYN ${ }^{4}$, Enyew \\ ADGO $^{5}$, Mitsuru TSUBO ${ }^{6}$, Derege T MESHESHA ${ }^{3,5}$, Tsugiyuki MASUNAGA ${ }^{7}$, Dagnachew \\ $\mathrm{AKLOG}^{8}$, Ayele A FENTA ${ }^{1}$, Kindiye EBABU ${ }^{1,5}$ \\ ${ }^{1}$ The United Graduate School of Agricultural Sciences, Tottori University, Tottori 680-8553, Japan; \\ ${ }^{2}$ School of Civil and Water Resource Engineering, Institute of Technology, Bahir Dar University, Bahir Dar, Ethiopia; \\ ${ }^{3}$ Arid Land Research Center, Tottori University, Tottori 680-0001, Japan; \\ ${ }^{4}$ International Platform for Dryland Research and Education, Tottori University, Tottori 680-0001, Japan; \\ ${ }^{5}$ Department of Natural Resources Management, Bahir Dar University, Bahir Dar, Ethiopia; \\ ${ }^{6}$ Institute for Soil, Climate and Water, Agricultural Research Council, Pretoria 0083, South Africa; \\ ${ }^{7}$ Faculty of Life and Environmental Science, Shimane University, Shimane Matsue 690-0823, Japan; \\ ${ }^{8}$ Center for International Affairs, Tottori University, Tottori 680-8550, Japan
}

\begin{abstract}
In developing countries such as Ethiopia, research to develop and promote soil and water conservation practices rarely addressed regional diversity. Using a water-balance approach in this study, we used runoff plots from three sites, each representing a different agro-ecological environment, e.g., high, mid and low in both elevation and rainfall, in the Upper Blue Nile Basin of Ethiopia to examine the runoff response and runoff conservation efficiency of a range of different soil and water conservation measures and their impacts on soil moisture. The plots at each site represented common land use types (cultivated vs. non-agricultural land use types) and slopes (gentle and steep). Seasonal runoff from control plots in the highlands ranged $214-560$ versus $253-475 \mathrm{~mm}$ at midlands and $119-200 \mathrm{~mm}$ at lowlands. The three soil and water conservation techniques applied in cultivated land increased runoff conservation efficiency by $32 \%$ to $51 \%$, depending on the site. At the moist subtropical site in a highland region, soil and water conservation increased soil moisture enough to potentially cause waterlogging, which was absent at the lowrainfall sites. Soil bunds combined with Vetiveria zizanioides grass in cultivated land and short trenches in grassland conserved the most runoff (51\% and 55\%, respectively). Runoff responses showed high spatial variation within and between land use types, causing high variation in soil and water conservation efficiency. Our results highlight the need to understand the role of the agro-ecological environment in the success of soil and water conservation measures to control runoff and hydrological dynamics. This understanding will support policy development to promote the adoption of suitable techniques that can be tested at other locations with similar soil, climatic, and topographic conditions.
\end{abstract}

Keywords: agro-ecology; drought-prone; runoff coefficient; runoff conservation efficiency; Ethiopia

Citation: Dagnenet SULTAN, Atsushi TSUNEKAWA, Nigussie HAREGEWEYN, Enyew ADGO, Mitsuru TSUBO, Derege T MESHESHA, Tsugiyuki MASUNAGA, Dagnachew AKLOG, Ayele A FENTA, Kindiye EBABU. 2018. Efficiency of soil and water conservation practices in different agro-ecological environments in the Upper Blue Nile Basin of Ethiopia. Journal of Arid Land, 10(2): 249-263. https://doi.org/10.1007/s40333-018-0097-8

\footnotetext{
*Corresponding author: Dagnenet SULTAN (E-mail: dags120@yahoo.com; dagnenetsultan@alrc.tottori-u.ac.jp) Received 2017-05-19; revised 2017-11-29; accepted 2017-12-07

(C) Xinjiang Institute of Ecology and Geography, Chinese Academy of Sciences, Science Press and Springer-Verlag GmbH Germany, part of Springer Nature 2018
} 


\section{Introduction}

Over the last three decades, the government of Ethiopia and a consortium of donors have invested substantial resources to develop and promote sustainable land management practices as part of efforts to improve environmental conditions, ensure sustainable and increased agricultural production, and reduce poverty (Herweg and Ludi, 1999; Nyssen et al., 2000; Kassie et al., 2009; Adgo et al., 2013; Adimassu et al., 2014; Amare et al., 2014; Haregeweyn et al., 2015, 2017). Some of the major physical soil and water conservation techniques being used in the country include short trenches, soil and stone bunds, cut-off drains, check dams, hillside terraces, area closures, Fanya juu (a Swahili word meaning 'throw uphill'), and Zai pits (a term in Burkina Faso used to refer digging pits that retain compost and direct water into the soil surrounding each plants to grow). Recently, physical structures have been combined with biological measures such as vegetation establishment to protect the soil against erosion (Amare et al., 2014). But despite these efforts, the sustainability of the development work is unclear. Due to low rates of adoption, most of the promoted practices have been only partially successful. In some cases, disadoption or reduced use of the techniques has been reported (Tadesse and Belay, 2004).

Past efforts to develop and promote soil and water conservation practices had neglected the pronounced regional diversity of Ethiopia. Haregeweyn et al. (2015) and Sultan et al. (2017) found that the impact of these interventions was influenced by both the type of measurement and the agroecosystem under which it was implemented. Landscape, land use, soils, hydrological processes, and climate can be highly variable across regions, and their linkages to the success of environmental management practices are important aspects that must be understood and documented (Melesse and Abtew, 2016). In addition, Bayabil et al. (2010) illustrated that the effectiveness of a soil and water conservation practice depends on whether watershed runoff processes depend primarily on the local ecosystem, topography, or a combination of the two. The suitability of any soil and water management practice depends greatly upon the soil, topography, climate, cropping system, and resources available to farmers (Pathak et al., 2009). Overall, an agro-ecological approach can contribute substantially to sustainable intensification of agriculture, but this must supported by an improved knowledge of the optimal conservation measure for each combination of site type and land use (Lampkin et al., 2015).

In Ethiopia, the distribution and amount of rainfall show great spatial and temporal variation, which is strongly influenced by altitude (Rientjes et al., 2013; Schmidt and Zemadim, 2013; Fenta et al., 2017a). Bekele-Tesemma et al. (2005) suggested that temperature (which is determined by the altitude) and rainfall are the two most important climatic factors that affect land management from the point of view of farmers or development agents. Hurni et al. (2016) developed general soil and water conservation guidelines in which they noted that climate varies greatly within Ethiopia, which ranges from dry to wet, and covers a range of elevations from lowlands to highlands. As a result, it is not possible to apply the same soil and water conservation techniques everywhere. This conclusion was based on a feasibility study of different physical conservation measures that had been tested in micro-watersheds (soil conservation research sites) in different agro-ecology systems that had been monitored 25 years ago (Herweg and Ludi, 1999).

Gradually, a few agro-ecology based studies have emerged, but most focused on evaluation of the socioeconomic aspects (Kassie et al., 2009; Matouš et al., 2013; Schmidt and Zemadim, 2013; Hurni et al., 2015; Nigussie et al., 2017). Studies on the efficiency of soil and water conservation are few, and most concentrated on the combination of a single agro-ecology with a specific conservation measure (Taye et al., 2013; Adimassu et al., 2014; Amare et al., 2014; Dagnew et al., 2015; Fenta et al., 2017b; Sultan et al., 2017). However, these studies also lack detailed information about the hydrological dynamics created by the conservation efforts across a range of land use, cover types, and slope classes. Best management practice should encompass a series of measures that are useful, proven to be effective, cost-effective, and generally accepted among conservation experts and the ultimate users for specific agro-ecology systems. Hence, critical analysis of the runoff responses and efficiency of the available measures under different agro-ecology systems is needed to evaluate which particular sustainable land management interventions are most likely to 
be successful in a given location. This suggests a need for analyses that examine the interactions between various location-specific factors. The results of such observations will provide greater insight into how soil and water conservation affects the hydrological processes under different agroecology systems. To provide some of the missing knowledge, we used plot-level runoff measurements and hydrological analyses at three different agro-ecological sites in the Amhara and Benishangul Gumuz administrative regions of Ethiopia. Our objectives were (1) to analyze the spatial variability of rainfall-runoff relationship and its controlling factors and (2) to determine the ability of different soil and water conservation practices to reduce runoff and improve soil moisture availability in typical agro-ecology systems in the Upper Blue Nile Basin of Ethiopia.

\section{Materials and methods}

\subsection{Study area}

We established experimental runoff plots to represent the different land use and cover types and different slope gradients at three experimental sites (Fig. 1): the Guder and Aba Gerima watersheds from the Fagita Lekoma $\left(10^{\circ} 57^{\prime}-11^{\circ} 11^{\prime} \mathrm{N}, 36^{\circ} 40^{\prime}-37^{\circ} 05^{\prime} \mathrm{E}\right)$ and Bahir Dar Zuria $\left(11^{\circ} 25^{\prime}-11^{\circ} 55^{\prime} \mathrm{N}\right.$, $37^{\circ} 04^{\prime}-37^{\circ} 39^{\prime} \mathrm{E}$ ) districts, respectively, of the Amhara Region, and the Dibatie watershed from the Dibatie District $\left(10^{\circ} 01^{\prime}-10^{\circ} 53^{\prime} \mathrm{N}, 36^{\circ} 04^{\prime}-36^{\circ} 26^{\prime} \mathrm{E}\right)$ of the Benishangul Gumuz Region. These sites were selected to represent three important agro-ecology systems in the Upper Blue Nile Basin having different annual precipitation, elevation, experiences with soil and water conservation, soil erosion rates, and land use types (Tables 1 and 2).

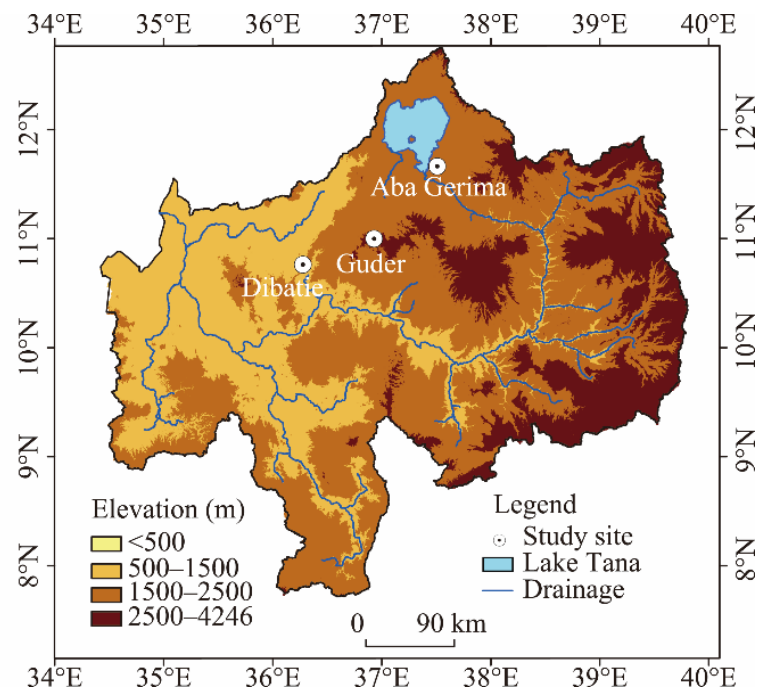

Fig. 1 Location of the study sites with different agro-ecology systems

Each study site has been part of the national government's regular extension programs and other public based soil and water conservation interventions, but the experiences of these study sites with other externally funded programs have varied greatly (Nigussie et al., 2017). The Aba Gerima watershed has been part of the Water and Land Resource Centre, which is funded by the Swiss Agency for Development and Cooperation, since 2011. The Guder watershed has received support for soil and water conservation initiatives from the World Bank under the Sustainable Land Management Programme since 2008. Dibatie has had no external funding support for conservation projects. The major but most common soil and water conservation measures implemented in the Upper Blue Nile Basin of Ethiopia are the creation of soil bunds (i.e., raised soil embankment from the ditch is moved downhill that block the flow of water), Fanya juu (i.e., raised soil embankment from the ditch is moved upslope), short trenches (i.e., excavating trenches along the contour at the hillside), and soil bunds combined with vegetation establishment to protect the soil 
(Haregeweyn et al., 2015; Fig. 2). Soil bunds and Fanya juu were constructed by building soil walls (about $0.5-1.0 \mathrm{~m}$ high) along the contour have similar dimensions of $1.6 \mathrm{~m}$ wide and $6.0 \mathrm{~m}$ long with variable spacing depending on land use and slope. Soil faced short trenches were constructed by excavating trenches of $0.5 \mathrm{~m}$ deep, $1.4 \mathrm{~m}$ wide and $1.5-2.5 \mathrm{~m}$ long with spacing between trenches of $1.7 \mathrm{~m}$ along the contour.

Although the overall slope at each site does not change, the effective slope length (the distance between conservation structures) decreases; the principle is to reduce the speed of the flowing water when it contacts each structure and the volume of water that reaches the slope downhill of that structure, thereby reducing the runoff volume. Soil and water conservation measures are applied to even and uneven grounds in the Upper Blue Nile Basin by using different designs.

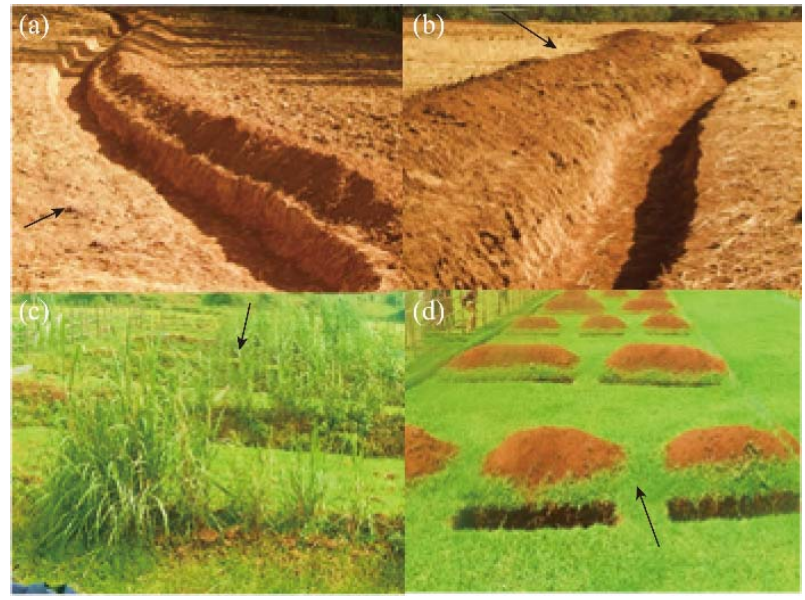

Fig. 2 Commonly implemented soil and water conservation measures for the major land use types in the three agro-ecology systems in the Upper Blue Nile Basin of Ethiopia. (a), soil bunds; (b), Fanya juu in cultivated land; (c), soil bunds combined with planting of vegetation (here, elephant grass) in cultivated land; and (d), short trenches in grazing land. The arrows indicate the slope direction.

\subsection{Instrumentation and data collection}

Each study site was equipped with a temperature sensor and datalogger (Mini-diver, Schlumberger Water Services, Netherland) and one manual rain gauge. The datalogger was programmed to measure the maximum and minimum air temperature at 10 -min intervals. We screened this data by taking the maximum and minimum temperatures from 144 readings and calculated a daily average temperature, which we used to calculate potential evapotranspiration at each site. The rain gauge recorded daily rainfall in the rainy season from June to October 2015 . More than $86 \%$ of the rainfall in the region is concentrated in these months (Sultan et al., 2017).

We measured runoff at the plot scale using a total of 42 runoff plots $(30 \mathrm{~m}$ long $\times 6 \mathrm{~m}$ wide each) in the three agro-ecology systems with 18 at Guder, 12 at Aba Gerima, and 12 at Debatie. We used four treatmentsfor the cultivated land on gentle and steep slopes; and two treatments for the nonagricultural land on steep slopes. Each agro-ecology system comprised cultivated land in two slope ranges ( $5 \%$ and $15 \%)$, grazing land (15\% slope), and degraded bush (35\% slope) plots. However; the Guder site had two additional main land use types, Acacia decurrens plantations (5\% and 25\% slopes), and Eucalyptus spp. plantations (25\% slopes). We divided the plots into a group with gentle slopes $\left(<15^{\circ}\right)$ and a group with steep slopes $\left(\geq 15^{\circ}\right)$.

Each cultivated land plot had a different soil and water conservation treatment (soil bund, Fanya juu, soil bund with vegetation establishment, and a control without treatment). Each other nonagricultural land use types (grazing land, degraded bush, A. decurrens plantations, and Eucalyptus spp. plantations) each had two treatments (short trenches and control). Based on their availability of sufficient soil and plant species and the ongoing sustainable land management practices, details of the soil bund with vegetation establishment treatment varied among the sites. In the Guder cultivated land plots, the soil bunds were reinforced and stabilized by planting vegetation such as 
tree lucerne (Cytisus proliferus) and densho grass (Pennisetum pedicellatum) together, whereas elephant grass (Pennisetum purpureum) and vetiver grass (Vetiveria zizanioides) were planted at the Aba Gerima and Debatie sites, respectively.

At the lower end of each plot, we excavated a $9.7-\mathrm{m}^{3}$ pit with a trapezoidal cross section (Fig. 3 ) and lined the pit with an impermeable geomembrane plastic to permit the collection of sediment and runoff. The pits were designed to accommodate the maximum runoff that would result from extreme rainfall events, predicted using the anticipated rainfall (based on historical records at the nearest meteorological station) and a runoff coefficient of 46\% (Herweg and Ludi 1999; Haregeweyn et al., 2016). The runoff depth corresponding to each daily rainfall was recorded and used for our runoff analysis. An equation that related the water depth in the pit to the volume of the pit was established for each trapezoidal pit by adding a known volume of water. Then, based on this relationship, the runoff volume was calculated from runoff depth measurements taken every morning at around 08:00 am LST with a measuring tape at an average of six points in the pit to account for variations in water depth due to bottom irregularities. The effect of direct rain falling into the pit (estimated from the rain gauges) was subtracted from the total. The plots were also bounded at the sides to prevent inflows of runoff and sediment from the sides of the plot using sheets of corrugated metal inserted into the ground to a depth of $15 \mathrm{~cm}$ and protruding $20 \mathrm{~cm}$ above the ground (Fig. 3c). Finally, the runoff depth was calculated by dividing the net runoff volume collected from the pit to the runoff plot area.

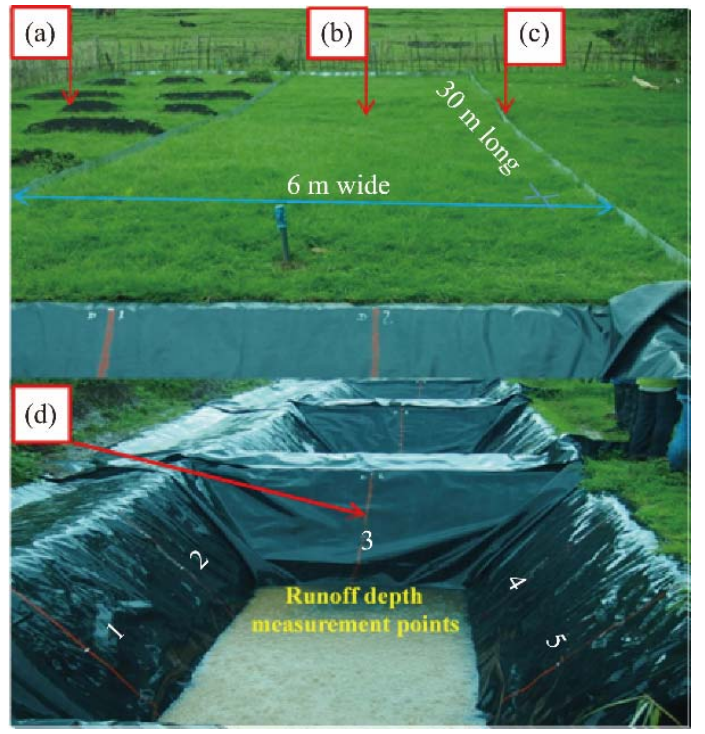

Fig. 3 Layout of the runoff plots established in grazing land in the Guder watershed. (a), plots with soil and water conservation measures; (b), plots without conservation measures; (c), corrugated iron sheets inserted in the ground to a depth of $15 \mathrm{~cm}$ to establish the plot boundaries; (d), runoff collection pit lined with impermeable geomembrane plastic. Water depth was measured at the six numbered points (1-6) on the liner (Sultan et al., 2017), with the point No. 6 in the opposite side of No. 3 .

The values of various soil variables were determined to characterize each site (Table 1). Three samples were taken from the top $30 \mathrm{~cm}$ of the soil profile at intervals of $10 \mathrm{~cm}$ for each land use type and analyzed to determine the texture using the hydrometric method (Sheldrick and Wang, 1993) and the average of the particle-size distributions were used to characterize the site. Undisturbed soil samples were taken to a depth of $30 \mathrm{~cm}$ at $10-\mathrm{cm}$ intervals using a core sampler with a volume of $100 \mathrm{~cm}^{3}$ to determine the soil bulk density to determine the bulk density. The samples were then oven-dried at $105^{\circ} \mathrm{C}$ for $24 \mathrm{~h}$ and weighed. The bulk density was determined by dividing the weight of the oven-dried soil samples by the volume of the soil core. Soil penetration resistance $(\mathrm{SPR}(\mathrm{kPa}))$ was measured by using a hand-operated soil cone penetrometer 
(Hand penetrometer, Eijkelkamp Company, the Netherlands) with a cone $\left(2-\mathrm{cm}^{2}\right.$ base size) and a driving shaft graduated at $5-\mathrm{cm}$ intervals. For each site, we calculated the SPR as the average of 30 observations.

Table 1 Main characteristics of research sites

\begin{tabular}{|c|c|c|c|}
\hline Characteristics & Dibatie & Aba Gerima & Guder \\
\hline Mean elevation (m a.s.1.) & $\begin{array}{c}1490 \\
\text { Lowland }\end{array}$ & $\begin{array}{c}1998 \\
\text { Midland }\end{array}$ & $\begin{array}{c}2728 \\
\text { Highland }\end{array}$ \\
\hline Mean daily temperature $\left({ }^{\circ} \mathrm{C}\right)$ & $18-29$ & $17-31$ & $15-24$ \\
\hline Mean annual precipitation (mm) & 1022 & 1343 & 2495 \\
\hline Major soil texture class & Clay & Clay & Clay loam \\
\hline Soil types & Vertisols, Nitosols & Nitosols, Leptosols & Acrisols, Nitosols \\
\hline Soil bulk density $\left(\mathrm{g} / \mathrm{cm}^{3}\right)$ & $1.11-1.44$ & $1.21-1.40$ & $0.83-1.34$ \\
\hline Average soil penetration resistance $(\mathrm{kPa})$ & 2400 & 2200 & 1639 \\
\hline Agro-ecology zone $^{a}$ & $\begin{array}{l}\text { Tropical hot humid } \\
\text { (Moist Kolla) }\end{array}$ & $\begin{array}{l}\text { Humid subtropical } \\
\text { (Moist Weyna Dega) }\end{array}$ & $\begin{array}{l}\text { Moist subtropical } \\
\text { (Wet Dega) }\end{array}$ \\
\hline Dominant crops ${ }^{\mathrm{b}}$ & $\begin{array}{l}\text { Finger millet, teff, } \\
\text { maize, groundnut }\end{array}$ & $\begin{array}{l}\text { Teff, finger millet, } \\
\text { wheat, maize, khat }\end{array}$ & $\begin{array}{c}\text { Barley, teff, wheat, } \\
\text { potatoes }\end{array}$ \\
\hline Soil erosion severity ${ }^{\mathrm{c}}$ & Slight & Moderate & Very severe \\
\hline Rainfall erosivity & High & Very high & Very high \\
\hline Soil and water conservation activities & Low & High & Medium \\
\hline
\end{tabular}

Note: Moist Kolla, 500-1500 m a.s.l., mean annual precipitation of 900-1400 mm; Moist Weyna Dega, 1500-2300 m a.s.1., mean annual precipitation of 900-1400 mm; Wet Dega, 2300-3200 m a.s.l. and mean annual precipitation of $\geq 1400 \mathrm{~mm}$ (Hurni et al., 2016; Nigussie et al., 2017); Slight, 5-15 Mg/(hm² •a); Moderate, $15-30 \mathrm{Mg} /\left(\mathrm{hm}^{2} \cdot \mathrm{a}\right)$; Very severe, $\geq 50 \mathrm{Mg} /\left(\mathrm{hm}^{2} \cdot a\right)$ (Haregeweyn et al., 2017). a, Sultan et al. (2017); ${ }^{\text {b }}$, Nigussie et al. (2016); ${ }^{\mathrm{c}}$, Ebabu (2016).

Table 2 summarizes the characteristics of the soil and water conservation measures implemented in the runoff plots. The slope of the plot was measured with a clinometer (PM-5/360 PC Clinometer, Suunto, Finland). The dimensions of each conservation measure were based on the standard practices in the study area. The short trenches were installed in two rows across the slope by excavating the soil to a depth of $0.5 \mathrm{~m}$ : the upslope row comprised shorter lengths $(1.4 \mathrm{~m} \times 1.5 \mathrm{~m})$ separated by $0.5 \mathrm{~m}$ and the downslope row comprised longer lengths $(1.4 \mathrm{~m} \times 2.5 \mathrm{~m}$ for the $A$. decurrens, grazed grassland, Eucalyptus spp., and degraded bush sites; $1.6 \mathrm{~m} \times 6.0 \mathrm{~m}$ for the cultivated sites; Table 2). The long and short axis of the excavations were oriented perpendicular to the slope.

\subsection{Data analysis}

We analyzed the plot data for seasonal runoff, runoff coefficient (RC), runoff conservation efficiency (RCE), and seasonal soil moisture availability. We quantified the relationships between daily rainfall and runoff depth by means of regression analysis. RC was calculated by Equation 1 .

$$
\mathrm{RC}=(\text { Runoff depth } / \text { Rainfall depth }) \times 100 \% \text {. }
$$

Runoff conservation efficiency (RCE) in each plot was calculated relative to runoff in the corresponding control plot using Equation 2 (Herweg and Ludi, 1999; Sahoo et al., 2016).

$$
\mathrm{RCE}=\frac{(A-B)}{A} \times 100 \%,
$$

where $A$ is the runoff loss $(\mathrm{mm})$ from the control plot and $B$ is the runoff loss $(\mathrm{mm})$ from the corresponding plot with a conservation measure.

Seasonal moisture conservation efficiency was measured by the change in seasonal water availability analyzed for all runoff plots using the water-balance equation (Eq. 3; Dingman, 2015).

$$
\Delta S=P-Q-\mathrm{ET},
$$

where $\Delta S(\mathrm{~mm})$ is the seasonal change in moisture stored in the soil (including deep percolation beyond the soil zone); $P$ is the seasonal precipitation $(\mathrm{mm}) ; Q$ is seasonal measured runoff $(\mathrm{mm})$; and ET is seasonal evapotranspiration $(\mathrm{mm})$. Since accurate field measurements are often difficult 
to acquire, evapotranspiration is usually estimated as the potential evapotranspiration (PET). Given the limited long-term meteorological data available for the study watersheds, we used the temperature-based method (Eq. 4) developed by Hargreaves and Samani (1985) to calculate PET.

$$
\mathrm{PET}=0.0023 \times R_{a} \times\left[\frac{T_{\max }+T_{\min }}{2}+17.8\right] \times\left(T_{\max }-T_{\text {min }}\right)^{0.5},
$$

where $R_{a}$ is the solar radiation ( $\mathrm{mm} /$ day) estimated based on the approach suggested by Allen et al. (1998); $T_{\max }$ is the daily maximum temperature $\left({ }^{\circ} \mathrm{C}\right)$ and $T_{\min }$ is the daily minimum temperature $\left({ }^{\circ} \mathrm{C}\right)$.

Table 2 Characteristics of the $30 \mathrm{~m} \times 6 \mathrm{~m}$ runoff plots used to study the effects of land use and soil and water conservation (SWC) practices on runoff in Ethiopia

\begin{tabular}{|c|c|c|c|c|c|c|c|c|c|}
\hline \multirow{2}{*}{$\begin{array}{l}\text { Land use } \\
\text { type }\end{array}$} & \multirow{2}{*}{$\begin{array}{l}\mathrm{SWC} \\
\text { treatment }\end{array}$} & \multirow{2}{*}{$\frac{\text { Slope }}{(\%)}$} & \multirow{2}{*}{$\frac{\text { Spacing }}{(\mathrm{m})}$} & \multicolumn{2}{|c|}{$\begin{array}{c}\text { Dimension of SWC } \\
\text { structure }\end{array}$} & \multirow{2}{*}{ Number of SWC per plot } & \multicolumn{3}{|c|}{$\begin{array}{l}\text { Number of plots per land use } \\
\text { type } \times \text { slope group }\end{array}$} \\
\hline & & & & Short (m) & Long (m) & & Guder & $\begin{array}{c}\text { Aba } \\
\text { Gerima }\end{array}$ & Debatie \\
\hline \multirow[t]{4}{*}{ CL1 } & Control & 5 & - & - & - & 0 & 4 & 4 & 4 \\
\hline & Soil bund & & 7.8 & - & $1.6 \times 6.0$ & 3 & & & \\
\hline & Fanya juu & & 7.8 & - & $1.6 \times 6.0$ & 3 & & & \\
\hline & Soil bund & & 7.8 & - & $1.6 \times 6.0$ & 3 & & & \\
\hline \multirow[t]{4}{*}{ CL2 } & Control & 15 & - & - & - & 0 & 4 & 4 & 4 \\
\hline & Soil bund & & 5.5 & - & $1.6 \times 6.0$ & 4 & & & \\
\hline & Fanya juu & & 5.5 & - & $1.6 \times 6.0$ & 4 & & & \\
\hline & Soil bund & & 5.5 & - & $1.6 \times 6.0$ & 4 & & & \\
\hline \multirow[t]{2}{*}{$\mathrm{AD} 1$} & Control & 5 & - & - & - & 0 & 2 & - & - \\
\hline & Short trench & & 2.9 & $1.4 \times 1.5$ & $1.4 \times 2.5$ & 15 & & & \\
\hline \multirow[t]{2}{*}{$\mathrm{AD} 2$} & Control & 25 & - & - & - & 0 & 2 & - & - \\
\hline & Short trench & & 1.7 & $1.4 \times 1.5$ & $1.4 \times 2.5$ & 20 & & & \\
\hline \multirow[t]{2}{*}{ GR2 } & Control & 15 & - & - & - & 0 & 2 & 2 & 2 \\
\hline & Short trench & & 1.7 & $1.4 \times 1.5$ & $1.4 \times 2.5$ & 20 & & & \\
\hline \multirow[t]{2}{*}{ EP2 } & Control & 25 & - & - & - & 0 & 2 & - & - \\
\hline & Short trench & & 1.7 & $1.4 \times 1.5$ & $1.4 \times 2.5$ & 15 & & & \\
\hline \multirow[t]{2}{*}{ DB2 } & Control & 35 & - & - & - & 0 & 2 & 2 & 2 \\
\hline & Short trench & & 1.7 & $1.4 \times 1.5$ & $1.4 \times 2.5$ & 20 & & & \\
\hline
\end{tabular}

Note: CL, cultivated land; DB, degraded bush; AD, Acacia decurrens plantation; EP, Eucalyptus spp. plantation; GR, grazing land; 1 and 2 followed the land use types means gentle slope and steep slope, respectively. 0 indicates no soil and water conservation structure; -, not applicable; Fanya juu, a Swahili word meaning 'throw uphill'.

\section{Results and discussion}

\subsection{Runoff variability within and between agro-ecology systems}

Table 3 summarizes the cumulative rainfall and cumulative runoff during the rainy season, $\mathrm{RC}$, and RCE for all plots. The seasonal rainfall totaled $1568 \mathrm{~mm}$ for Guder, $1402 \mathrm{~mm}$ for Aba Gerima, and $881 \mathrm{~mm}$ for Debatie. The seasonal runoff from control plots in the Guder watershed ranged from 214 to $560 \mathrm{~mm}$, versus 253 to $475 \mathrm{~mm}$ at Aba Gerima and 119 to $200 \mathrm{~mm}$ at Debatie. The highest runoff was $560 \mathrm{~mm}$, in grazing land control plots on steep slopes at Guder (GR2), and the lowest was $81 \mathrm{~mm}$, in short trench plots on steep slopes at Debatie (DB2). The cumulative runoff was the lowest at Debatie, which was the site with by far the lowest precipitation. Changes in precipitation regimes clearly have the potential to profoundly affect runoff and soil erosion. Lee et al. (1996) confirmed that the precipitation had a linear relationship with runoff and soil erosion, with little difference in runoff response to a change in storm frequency or intensity. The grazing land site on a steep slope (GR2) generated the highest seasonal runoff at Guder $(560 \mathrm{~mm})$, followed by the same site type at Aba Gerima $(475 \mathrm{~mm})$ and Debatie $(134 \mathrm{~mm})$; the high runoff in Guder might be related to frequent trampling by animals because the site was used for grazing livestock. As a result, we 
found compacted topsoil surfaces in grazing lands, with the highest soil penetration resistance (SPR ranging from 1990 to $2210 \mathrm{kPa}$ ), versus a maximum of $1100-1660 \mathrm{kPa}$ for the other land use types. This reduced infiltration and thereby increased runoff. A similar analysis for the Upper Blue Nile Basin showed that cattle on wet grazing soils caused additional compaction in the top $30 \mathrm{~cm}$ soil layers (Tebebu et al., 2015), leading to higher runoff production.

Table 3 Runoff conservation efficiency (RCE) and runoff coefficient (RC) for the different land use types and different SWC practices in the three agro-ecology systems during the rainy season from June to October 2015

\begin{tabular}{|c|c|c|c|c|c|c|}
\hline Site & $\begin{array}{c}\text { Land use } \\
\text { type } \times \text { slope group }\end{array}$ & SWC treatment & $\begin{array}{l}\text { Cumulative rainfall } \\
(\mathrm{mm})\end{array}$ & $\begin{array}{l}\text { Cumulative runoff } \\
(\mathrm{mm})\end{array}$ & $\begin{array}{l}\text { Runoff conservation } \\
\text { efficiency }(\%)\end{array}$ & $\begin{array}{c}\text { Seasonal RC } \\
(\%)\end{array}$ \\
\hline \multirow[t]{12}{*}{ Guder } & $\mathrm{CL}_{\mathrm{av}}$ & Control & $1567.6 \pm 13.4$ & $401.0 \pm 1.6$ & - & 26.00 \\
\hline & & Soil bund & & $272.4 \pm 1.5$ & 32.1 & 17.41 \\
\hline & & Fanya juu & & $264.3 \pm 1.6$ & 34.1 & 16.91 \\
\hline & & Soil bund & & $271.7 \pm 1.8$ & 32.2 & 17.30 \\
\hline & GR2 & Control & & $560.4 \pm 4.2$ & - & 35.70 \\
\hline & & Short trench & & $313.4 \pm 2.1$ & 44.0 & 20.00 \\
\hline & DB2 & Control & & $214.3 \pm 1.8$ & - & 13.70 \\
\hline & & Short trench & & $157.5 \pm 1.4$ & 27.0 & 10.00 \\
\hline & $\mathrm{AD}_{\mathrm{av}}$ & Control & & $396.0 \pm 5.1$ & - & 25.30 \\
\hline & & Short trench & & $211.3 \pm 1.8$ & 47.0 & 13.53 \\
\hline & EP2 & Control & & $217.4 \pm 2.2$ & - & 13.83 \\
\hline & & Short trench & & $155.5 \pm 2.0$ & 28.0 & 10.00 \\
\hline \multirow[t]{8}{*}{ Dibatie } & $\mathrm{CL}_{\mathrm{av}}$ & Control & $881.2 \pm 11.7$ & $199.7 \pm 3.0$ & - & 22.70 \\
\hline & & Soil bund & & $103.4 \pm 1.2$ & 48.0 & 11.70 \\
\hline & & Fanya juи & & $105.4 \pm 1.2$ & 47.0 & 12.00 \\
\hline & & Soil bund & & $97.3 \pm 1.2$ & 51.0 & 11.00 \\
\hline & GR2 & Control & & $134.4 \pm 2.6$ & - & 15.30 \\
\hline & & Short trench & & $101.5 \pm 1.8$ & 25.0 & 11.50 \\
\hline & DB2 & Control & & $119.4 \pm 2.3$ & - & 13.60 \\
\hline & & Short trench & & $81.4 \pm 1.2$ & 32.0 & 9.20 \\
\hline \multirow[t]{8}{*}{ Aba Gerima } & $\mathrm{CL}_{\mathrm{av}}$ & Control & $1401.5 \pm 13.7$ & $253.3 \pm 4.0$ & - & 18.00 \\
\hline & & Soil bund & & $158.1 \pm 3.2$ & 38.0 & 11.30 \\
\hline & & Fanya juи & & $165.6 \pm 2.5$ & 35.0 & 11.80 \\
\hline & & Soil bund & & $163.4 \pm 2.6$ & 36.0 & 11.70 \\
\hline & GR2 & Control & & $475.0 \pm 7.2$ & - & 40.00 \\
\hline & & Short trench & & $213.8 \pm 2.6$ & 55.0 & 15.30 \\
\hline & DB2 & Control & & $275.5 \pm 3.9$ & - & 19.70 \\
\hline & & Short trench & & $151.8 \pm 2.1$ & 45.0 & 10.80 \\
\hline
\end{tabular}

Note: $\mathrm{Cl}_{\mathrm{av}}$, average for cultivated land in both slope classes (CL1 and CL2 in Table 2); $\mathrm{AD}_{\mathrm{av}}$, average for A. decurrens plantations in land with gentle and steep slopes; -, not applicable. Mean \pm SD.

Although higher surface runoff is expected from control plots on steeper slopes (35\%), surface runoff from plots with degraded bush was lower than that from the other land use types, except for cultivated land at Aba Gerima (Table 3). This can be explained, on the one hand, by the direct effect of raindrop interception by the vegetation canopy, which dissipates their energy and creates infiltration pathways (Morgan et al., 1986; Castillo et al., 1997; Descroix et al., 2001). On the other hand, vegetation decreases runoff indirectly by improving soil physical properties through the incorporation of organic matter (16.7\% in Guder; Sultan et al., 2017) and loosening of the soil by growing roots, thereby increasing the infiltration rate (Descheemaeker et al., 2006). Taye et al. (2013) explained this in a different way; they reported that RC decreased with increasing slope due to an increase in the content of coarse particles in the soil, which promoted infiltration. Similarly, Tebebu et al. (2015) illustrated that, for saturation-excess runoff, water infiltrates on hillsides and erosion-inducing runoff occurs in the flatter, downslope parts of landscapes. This, in turn, affects 
the hydrology, since excess water flows more rapidly to valley bottoms as lateral flow, leading to gully formation (Bayabil et al., 2010). All of these factors may have combined to overwhelm the slope effect.

\subsection{Variability of rainfall-runoff responses within and across the three agro-ecosystems}

Taking into account the interactions between the soil and water conservation measures and the two dominant land use types, which were cultivated land on steep slopes (CL2) and grazing land (GR2), we calculated the rainfall thresholds required to generate runoff for both of these at each agroecology system (Fig. 4; Table 4). The threshold rainfall can be determined by plotting the daily runoff depth against the corresponding rainfall depth (Fig. 4) and performing least-squares regression (Descheemaeker et al., 2006; Girmay et al., 2009). The slope of the regression line represents how rapidly runoff depth increases with increasing rainfall depth after the rainfall threshold is exceeded. The threshold rainfall values were selected based on the probability of $80 \%$ of events below the threshold level rainfall failing to produce runoff. The higher the rainfall threshold and the lower the slope of the curve, the higher the infiltration rate and greater the storage capacity of the soil in the agro-ecology system (Descheemaeker et al., 2006; Girmay et al., 2009).
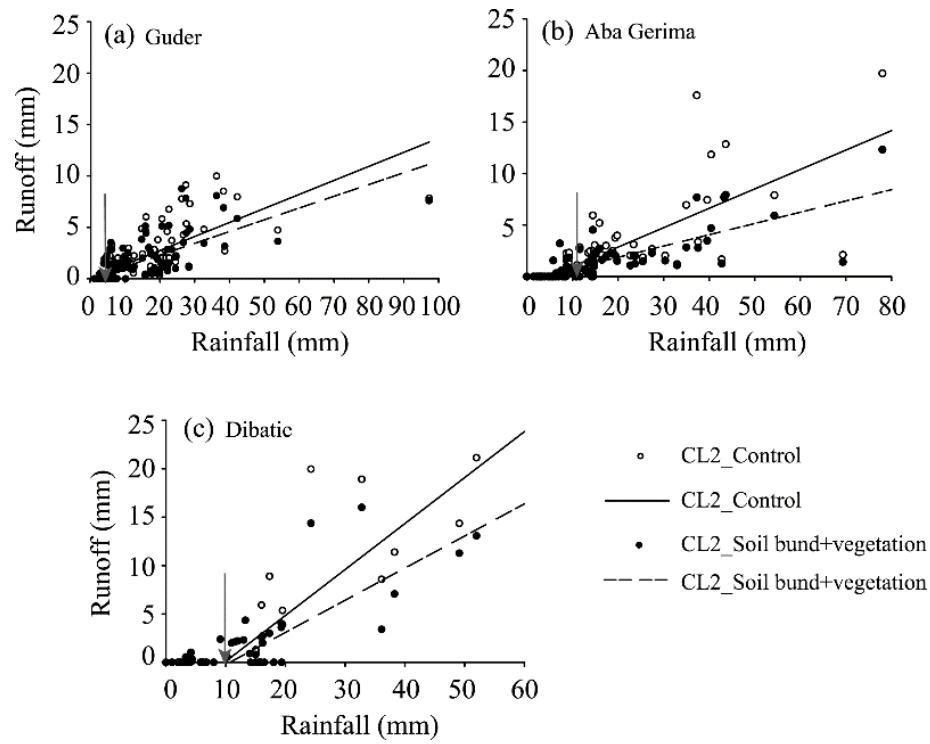

Fig. 4 Regressions of runoff as a function of rainfall (excluding the events that produced no runoff) and its use to determine the rainfall thresholds (arrows) for six plot types: CL2_Control, cultivated control plots on steep slopes; CL2_Soil bund+vegetation, cultivated plots on steep slopes with a soil bund combined with vegetation establishment.

The biggest rainfall event at Guder was $97 \mathrm{~mm}$, versus $78 \mathrm{~mm}$ at Aba Gerima and $53 \mathrm{~mm}$ at Debatie. In the Guder watershed, the rainfall threshold values for runoff generation were 6 and 5 $\mathrm{mm}$ in cultivated land (CL2) and grazing land (GR2) on steep slopes, respectively (Table 4). For the same land use types, the largest rainfall threshold values were obtained at the Dibatie and Aba Gerima sites, with thresholds of more than 10 and $9 \mathrm{~mm}$, respectively. The slope of the rainfallrunoff curve also varied widely among the plots; with the values of $0.10-0.45$. The soil and water conservation practices using vegetated soil bunds and short trenches in the cultivated and grazing land plots resulted in a lower slope of the curve than in the corresponding control plots at all three sites (Table 4). This can be attributed to storage of runoff in depressions and slowing of the runoff flow by the conservation structures.

The response of runoff to rainfall at the moist subtropical site (Guder) began sooner (i.e., a lower rainfall threshold) than that at the humid subtropical (Aba Gerima) and the tropical hot humid (Debatie) sites (Table 4). Sultan et al. (2017) reported that Guder receives long-lasting rainfall events with small amounts of rainfall, and yet that this site has a longer rainy season than other 
sites in the western and central highlands; nonetheless, the higher proportion of rainfall $(63 \%)$ that comes from light rainfall events, which influences subsequent availability of soil moisture. In addition, the heavy soils of the Guder watershed (Table 1) tend to retain moisture for a longer period, and this can lower the threshold rainfall compared with other sites. Therefore, small increases in precipitation could result in waterlogging and damage to soil and water conservation structures if subsequent precipitation occurs as intense storms that deposit more rain than the threshold value.

On average, the rainfall threshold values at our study sites are higher than those in semi-arid regions of northern Ethiopia (the Tigray region). For example, Descheemaeker et al. (2006) obtained rainfall threshold values ranging from 3 to $16 \mathrm{~mm}$ in plots with different land use types. Similarly, Girmay et al. (2009) reported that rainfall events $>2 \mathrm{~mm}$ produced runoff in cultivated land, whereas rainfall events $>3 \mathrm{~mm}$ produced runoff in both grazing land and plantation areas. This illustrates the lower interception capacity of vegetation canopies at semi-arid sites and the lower infiltration capacity of soils in drier environments (Pilgrim et al., 1988). It is worth noting that the experimental plot dimensions $(5 \mathrm{~m} \times 2 \mathrm{~m}$ and $10 \mathrm{~m} \times 2 \mathrm{~m}$ in the previous studies, both of which were much smaller than the dimensions in the present study) can strongly affect the results of such studies, as the runoff amount is strongly influenced by scale effects (Bergkamp, 1998).

Table 4 Rainfall threshold $(T)$ required to generate runoff, and slope of the rainfall-runoff curve for each plot at the three study sites.

\begin{tabular}{cclcccc}
\hline Site & Plot code & SWC treatment & T (mm) & Slope & $R^{2}$ & $n$ \\
\hline Guder & CL2 & Control & 6 & 0.107 & $0.35^{*}$ & 70 \\
& CL2 & Soil bund & & 0.097 & $0.37^{*}$ & 70 \\
& GR2 & Control & 5 & 0.062 & $0.03^{*}$ & 75 \\
Aba Gerima & GR2 & Short trench & & 0.041 & $0.03^{*}$ & 75 \\
& CL2 & Control & 11 & 0.182 & $0.41^{*}$ & 45 \\
& CL2 & Soil bund & & 0.109 & $0.45^{*}$ & 45 \\
Debatie & GR2 & Control & 9 & 0.412 & $0.38^{*}$ & 46 \\
& GR2 & Short trench & & 0.128 & $0.34^{*}$ & 46 \\
& CL2 & Control & 10 & 0.450 & $0.67^{*}$ & 36 \\
& CL2 & Soil bund & & 0.310 & $0.53^{*}$ & 36 \\
& GR2 & Control & 9 & 0.298 & $0.62^{*}$ & 38 \\
\hline
\end{tabular}

Note: $n$, number of observations; ${ }^{*}$, regression significance at $P<0.05$ level.

\subsection{Effects of soil and water conservation measures on RC and RCE}

The percentage of seasonal rainfall lost as runoff from control plots in the Guder watershed ranged from $14 \%$ to $36 \%$, versus $18 \%$ to $40 \%$ at Aba Gerima and $14 \%$ to $23 \%$ at Dibatie (Table 3), demonstrating the high variability of RC across the three studied environments. RC also differed between the control and treatment plots at each site.

Monthly RC was the highest in July and August in most treatments and decreased during September and October at all sites (Fig. 5). This can be explained by decreasing rainfall at the end of the rainy season combined with increasing vegetation cover during the rainy season, which would decrease runoff generation.

The knowledge provided by the present study about the RC of various land use types under different agro-ecology systems is essential to support estimates of runoff from a given watershed under a given land use. This, in turn, can help land managers to design appropriate water-harvesting structures, such as drainage canals, waterways, and reservoirs, and to predict flood hazards (Adimassu and Haile, 2011; Haregeweyn et al., 2016).

At the Guder site, the RCE of the soil and water conservation measures ranged from $27 \%$ to $47 \%$, versus $25 \%$ to $51 \%$ at Dibatie and $35 \%$ to $55 \%$ at Aba Gerima (Table 3). In general, the highest RCE was obtained for plots treated with soil bunds combined with vegetation establishment 

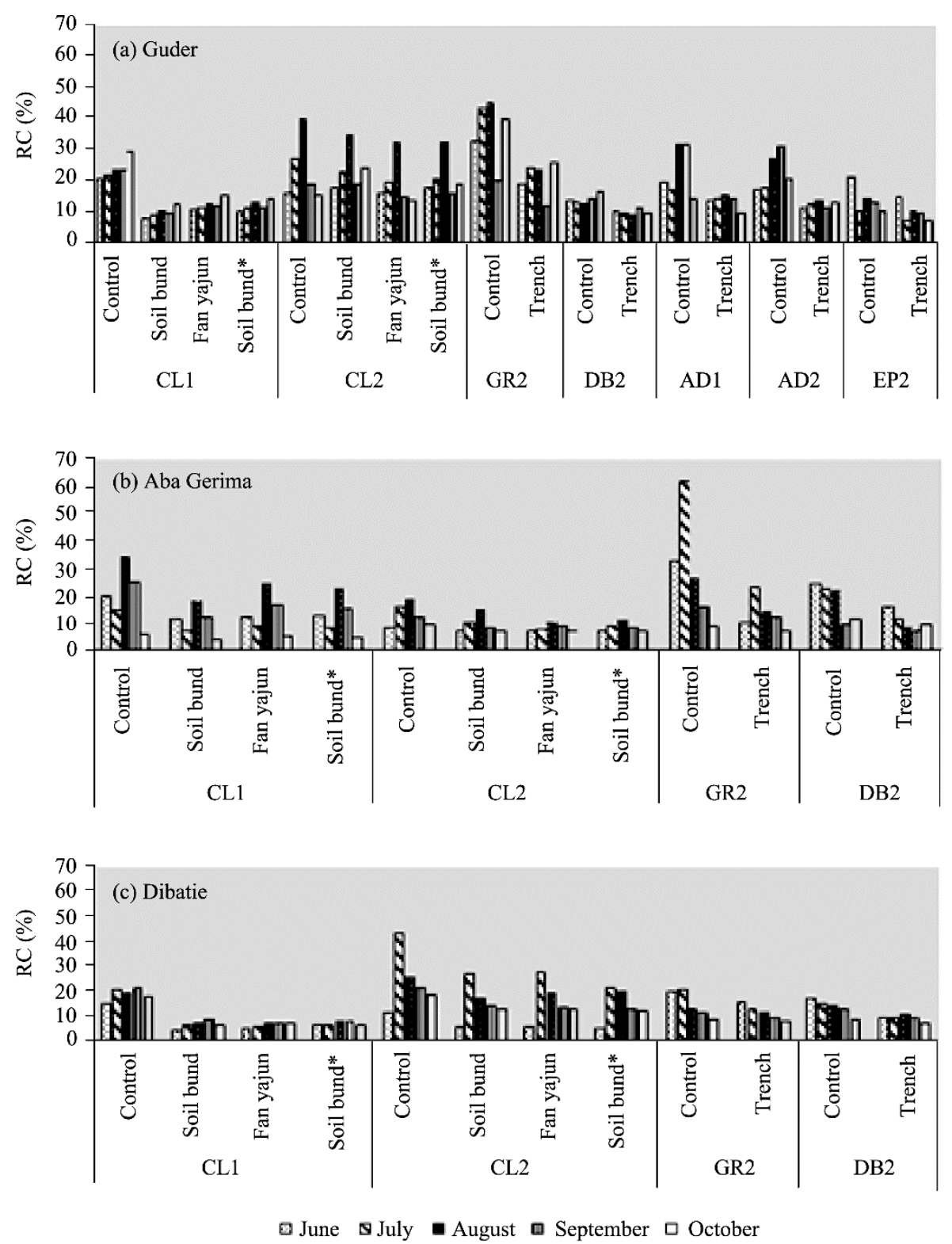

Fig. 5 Seasonal patterns of runoff coefficient (RC) values (\%) under different combinations of soil and water conservation measures and combinations of land use type. CL, cultivated land; GR, grazing land; AD, A. decurrens plantation; EP, Eucalyptus spp. plantation; DB, degraded bush; 1, gentle slope; 2 steep slope; *, soil bund combined with vegetation establishment.

based on the average for cultivated land. The soil bunds combined with vetiver grass ( $V$. zizanioides) at Debatie were more effective (RCE, 51\%) than those with tree lucerne (C. proliferus), densho grass ( $P$. pedicellatum; RCE, 32\%) and elephant grass ( $P$. purpureum; RCE, $36 \%$ ). In contrast, Amare et al. (2014) obtained the lowest runoff values for soil bunds combined with elephant grass, followed by soil bunds combined with the legume species Tephrosia in the northwestern Ethiopian highlands, and they also suggested that vetiver grass required a longer establishment period before it could begin to conserve soil and water efficiently. For the plots in non-agricultural land, the highest RCE (55\%) was obtained in GR2 plots treated with short trenches at the Aba Gerima site. On average, the establishment of soil and water conservation measures decreased runoff by $35 \%, 41 \%$, and $42 \%$ at the Guder, Debatie, and Aba Gerima sites, respectively. 
Thus, there is strong evidence that the adoption of soil and water conservation practices can reduce runoff more in areas with low rainfall than in areas with high rainfall. This is because dry soils have higher infiltration capacity than wet soils during the rainy season.

Higher RCE was obtained in all treatments in plots with a gentle slope than in the comparable treatment in plots with a steep slope due to the greater difference in runoff between the treated and control plots. In general, creating short trenches and soil bunds combined with vegetation establishment produce better runoff reduction than the other practices, especially in grazing land and cultivated land.

\subsection{Effects of soil and water conservation on soil moisture availability}

The combination of the distinctive features of the agro-ecology system, of the soil and water conservation practices, and of the associated hydrological processes affected the seasonal water availability in the plots (Fig. 6). The seasonal potential evapotranspiration values were 579, 675, and $732 \mathrm{~mm}$ for the Guder, Dibatie, and Aba Gerima sites, respectively, which were determined by the Hargreaves and Samani (1985) equation. The soil water availability (Fig. 6) obtained by means of the water-balance method ranged from 428 to 830,394 to 515 , and 7 to $124 \mathrm{~mm}$ for the Guder, Aba Gerima, and Dibatie sites, respectively. The differences in these ranges can be attributed to differences in the frequency of rainfall (amount), soil type, runoff amount (Table 3), and potential evaporation among the different agro-ecology systems. On average, implementation of soil and

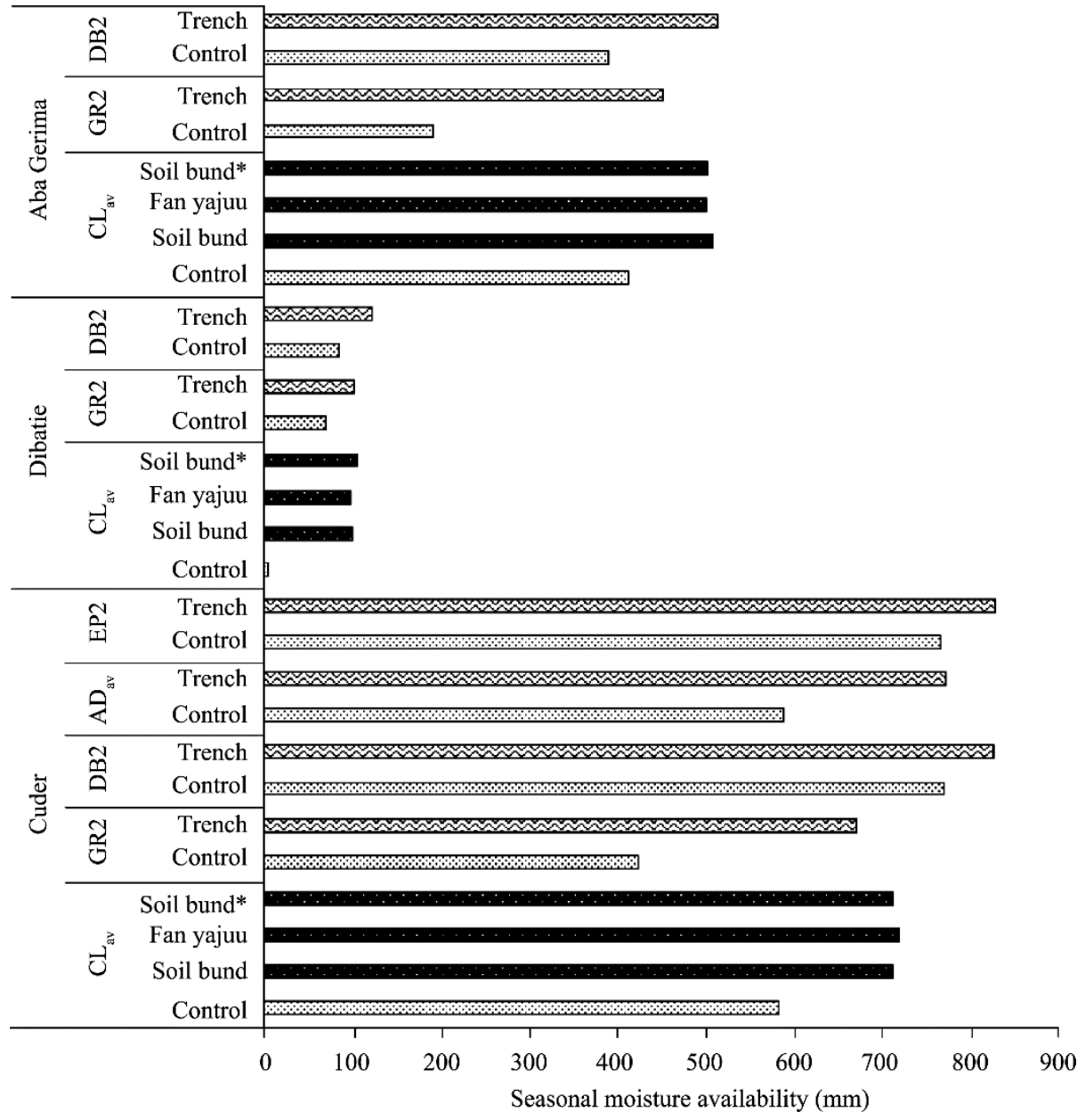

Fig. 6 Comparison of the effects of the different SWC practices on water availability during each month of the rainy season for the different agro-ecology systems. $\mathrm{Cl}_{\mathrm{av}}$, average for cultivated land in both slope classes (CL1 and CL2 in Table 2); ADav, average for A. decurrens plantations in land with gentle and steep slopes. 
water conservation measures increased seasonal water availability by about $139 \mathrm{~mm}$ compared with the control plot at the Guder site, versus 130 and $67 \mathrm{~mm}$ at the Aba Gerima and Debatie sites, respectively (Fig. 6). This indicates that the infiltration and runoff dynamics were also influenced by slope length, because the reduction of slope length caused by installation of the conservation structures increased storage and thereby reduced the volume of runoff.

Our results indicated that areas with higher rainfall (e.g., Guder) had higher potential soil moisture, and therefore a lower rainfall threshold to generate runoff. This decreased the conservation efficiency of the various soil and water conservation practices (Table 3). Consequently, the role of management practices was more important. It is more necessary to choose and design the optimal structure for these sites, i.e., where there is more runoff, there is more sediment transport capacity. Hence to control erosion and offsite transport of sediment, soil and water conservation planers need to focus on the safely disposal of the runoff to avoid risk of crop damage due to flooding or increase opportunities for sediment deposition from overland flow. This understanding helps to balance the soil erosion effect against the moisture retention/shedding effects of different measures.

Herweg and Ludi (1999) illustrated that runoff control requires a careful consideration of the design of soil and water conservation structures in relation to site characteristics. For example, in sub-humid or wetter areas with high rainfall, managers must prioritize both soil conservation and drainage of excess water. In addition, Nyssen et al. (2004) reported that in wet areas, investments in soil and water conservation may not be profitable at the farm level, although there are positive social benefits from controlling runoff and soil erosion at a regional level.

Although many of the methods discussed in this paper have been tried in the study area, they have not been widely adopted and have sometimes been dis-adopted where they were tried. To solve these problems, it will be necessary for the government and other stakeholders to increase knowledge transfer (extension) services to demonstrate the successful use of the techniques. In addition, the conservation structures all require ongoing maintenance. This agro-ecological classification and its related information assists in utilizing the research and field experience of one place to other places of identical soil, climatic and topographic conditions.

\section{Conclusions}

In this study, we provided an overview of the hydrological dynamics and effectiveness of soil and water conservation practices to reduce runoff under the common agro-ecology systems in the Upper Blue Nile Basin of Ethiopia. These results can guide managers towards the optimal choice of soil and water conservation measures under specific site conditions. Our study revealed that the responses of runoff and runoff conservation efficiency to soil and water conservation practices were highly variable both within and between agro-ecology systems. This high variation could be attributed to a combination of several factors such as the type of soil (permeability), land use types, soil water availability, the response of runoff to rainfall, and the prevailing climatic conditions (precipitation and potential evapotranspiration). These practices were highly effective in controlling runoff in the humid subtropical (Moist Weyna Dega) and tropical hot humid (Moist Kolla) agro-ecology systems, with average runoff reductions of $42 \%$ and $41 \%$, respectively. The moist subtropical region (Guder) had a higher potential soil moisture availability, but a lower rainfall threshold to generate runoff. From these findings, implementation of short trenches (humid subtropical) in grazing land maximized the efficiency in conserving runoff (55\%) due to temporary water storage in the short trenches, followed by infiltration. In contrast, vegetated bunds would be most effective in cultivated land, and short trenches would be effective in the two plantation types. Our results demonstrate the importance of studying each combination of agro-ecology system, site, and climate to scientifically determine the optimal conservation measures for that combination instead of making blanket recommendations for all systems that are likely to provide suboptimal results for many combinations. This understanding and the present results will help managers to choose the most effective conservation measures based on field trials and to test whether they will be equally applicable at other locations with similar soil, climatic, and topographic conditions. 


\section{Acknowledgements}

This research was supported by Grants-in-Aid for Scientific Research (25257417) from Japan Society for the Promotion of Science, Ministry of Education, Culture, Sports, Science and Technology, Japan.

\section{References}

Adgo E, Teshome A, Mati B. 2013. Impacts of long-term soil and water conservation on agricultural productivity: The case of Anjenie watershed, Ethiopia. Agricultural Water Management, 117: 55-61.

Adimassu Z, Haile N. 2011. Runoff, soil loss and their relationships under different land uses in the central highlands of Ethiopia. Ethiopian Journal of Applied Sciences \& Technology, 2(1): 39-49.

Adimassu Z, Mekonnen K, Yirga C, et al. 2014. Effect of soil bunds on runoff, soil and nutrient losses, and crop yield in the central highlands of Ethiopia. Land Degradation \& Development, 25(6): 554-564.

Allen R G, Pereira L S, Raes D, et al. 1998. Crop Evapotranspiration-Guidelines for Computing Crop Water Requirements-FAO Irrigation and Drainage Paper 56. Rome: FAO, 1-15.

Amare T, Zegeye A D, Yitaferu B, et al. 2014. Combined effect of soil bund with biological soil and water conservation measures in the northwestern Ethiopian highlands. Ecohydrology \& Hydrobiology, 14(3): 192-199.

Bayabil H K, Tilahun S A, Collick A S, et al. 2010. Are runoff processes ecologically or topographically driven in the (sub) humid Ethiopian highlands? The case of the Maybar watershed. Ecohydrology, 3(4): 457-466.

Bekele-Tesemma A, Sjohom H, Bekalo I, et al. 2005. Managing Land: A Practical Guidebook for Development Agents in Ethiopia. Nairobi: Regional Land Management Unit, World Agroforestry Centre, Eastern and Central Africa Regional Programme, Addis Ababa: Ministry of Agriculture and Rural Development, 282.

Bergkamp G. 1998. A hierarchical view of the interactions of runoff and infiltration with vegetation and microtopography in semiarid shrublands. CATENA, 33(3-4): 201-220.

Castillo V M, Martinez-Mena M, Albaladejo J. 1997. Runoff and soil loss response to vegetation removal in a semiarid environment. Soil Science Society of America Journal, 61(4): 1116-1121.

Dagnew D C, Guzman C D, Zegeye A D, et al. 2015. Impact of conservation practices on runoff and soil loss in the sub-humid Ethiopian Highlands: The Debre Mawi watershed. Journal of Hydrology and Hydromechanics, 63(3): 210-219.

Descheemaeker K, Nyssen J, Poesen J, et al. 2006. Runoff on slopes with restoring vegetation: a case study from the Tigray highlands, Ethiopia. Journal of Hydrology, 331(1-2): 219-241.

Descroix L, Viramontes D, Vauclin M, et al. 2001. Influence of soil surface features and vegetation on runoff and erosion in the Western Sierra Madre (Durango, Northwest Mexico). CATENA, 43(2): 115-135.

Dingman S L. 2015. Physical Hydrology ( ${ }^{\text {rd }}$ ed.). USA: Waveland Press, 17-39.

Ebabu K. 2016. Effects of land management practices on soil and nutrient losses: A case study in paired watersheds of Guder, in the Upper Blue Nile Basin, Ethiopia. MSc Thesis. Tottori, Japan: Tottori University, 108.

Fenta A A, Yasuda H, Shimizu K et al., 2017a. Spatial distribution and temporal trends of rainfall and erosivity in the Eastern Africa region. Hydrological Processes, 31(15): 4555-4567.

Fenta A A, Yasuda H, Shimizu K et al., 2017b. Response of streamflow to climate variability and changes in human activities in the semiarid highlands of northern Ethiopia. Regional Environmental Change, 17(4): 1229-1240.

Girmay G, Singh B R, Nyssen J, et al. 2009. Runoff and sediment-associated nutrient losses under different land uses in Tigray, Northern Ethiopia. Journal of Hydrology, 376(1-2): 70-80.

Haregeweyn N, Tsunekawa A, Nyssen J, et al. 2015. Soil erosion and conservation in Ethiopia: A review. Progress in Physical Geography, 39(6): 750-774.

Haregeweyn N, Tsunekawa A, Tsubo M, et al. 2016. Analyzing the hydrologic effects of region-wide land and water development interventions: a case study of the Upper Blue Nile basin. Regional Environmental Change, 16(4): 951-966.

Haregeweyn N, Tsunekawa A, Poesen J, et al. 2017. Comprehensive assessment of soil erosion risk for better land use planning in river basins: Case study of the Upper Blue Nile River. Science of the Total Environment, 574: 95-108.

Hargreaves G H, Samani Z A. 1985. Reference crop evapotranspiration from temperature. Applied Engineering in Agriculture, 1(2): 96-99.

Herweg K, Ludi E. 1999. The performance of selected soil and water conservation measures - case studies from Ethiopia and Eritrea. CATENA, 36(1-2): 99-114.

Hurni H, Zeleke G, Kassie M, et al. 2015. Economics of Land Degradation (ELD) Ethiopia case study. Soil degradation and sustainable land management in the Rainfed agricultural areas of Ethiopia: An assessment of the economic implications. In: 
Report for the Economics of Land Degradation Initiative. Bonn, Deutschland: Water and Land Resource Centre (WLRC); Centre for Development and Environment (CDE); Deutsche Gesellschaft für Internationale Zusammenarbeit (GIZ), 99.

Hurni H, Berhe W A, Chadhokar P, et al. 2016. Soil and Water Conservation in Ethiopia: Guidelines for Development Agents. Bern, Switzerland: Centre for Development and Environment (CDE), Bern Open Publishing (BOP), 1-50.

Kassie M, Zikhali P, Pender J, et al. 2009. Sustainable agricultural practices and agricultural productivity in Ethiopia: does agroecology matter? In: Working Papers in Economics No. 406. Göteborg: University of Gothenburg.

Lampkin N H, Pearce B D, Leake A R, et al. 2015. The role of agroecology in sustainable intensification. In: Report for the Land Use Policy Group. Organic Research Centre, Elm Farm and Game \& Wildlife Conservation Trust, Scottish.

Lee J J, Phillips D L, Dodson R F. 1996. Sensitivity of the US corn belt to climate change and elevated $\mathrm{CO}_{2}$ : II. Soil erosion and organic carbon. Agricultural Systems, 52(4): 503-521.

Matouš P, Todo Y, Mojo D. 2013. Roles of extension and ethno-religious networks in acceptance of resource-conserving agriculture among Ethiopian farmers. International Journal of Agricultural Sustainability, 11(4): 301-316.

Melesse A M, Abtew W. 2016. Landscape Dynamics, Soils and Hydrological Processes in Varied Climates. Cham: Springer International Publishing, 1-93.

Morgan R P C, Finney H J, Lavee H, et al. 1986. Plant cover effects on hillslope runoff and erosion: evidence from two laboratory experiments. In: Abrahams A D. Hillslope Processes. Winchester, Mass: Allen and Urwin, 16: 77-90.

Nigussie Z, Tsunekawa A, Haregeweyn N, et al. 2017. Farmers' perception about soil erosion in Ethiopia. Land Degradation \& Development, 28(2): 401-411.

Nyssen J, Haile M, Moeyersons J, et al. 2000. Soil and water conservation in Tigray (Northern Ethiopia): the traditional dagat technique and its integration with introduced techniques. Land Degradation \& Development, 11(3): 199-208.

Nyssen J, Poesen J, Moeyersons J, et al. 2004. Human impact on the environment in the Ethiopian and Eritrean highlands-a state of the art. Earth-Science Reviews, 64(3-4): 273-320.

Pathak P, Mishra P K, Rao K V, et al. 2009. Best-bet options on soil and water conservation. In: Best-bet Options for Integrated Watershed Management Proceedings of the Comprehensive Assessment of Watershed Programs in India, 25-27 July 2007. Andhra Pradesh, India: ICRISAT Patancheru, 75-94.

Pilgrim D H, Chapman T G, Doran D G. 1988. Problems of rainfall-runoff modelling in arid and semiarid regions. Hydrological Sciences Journal, 33(4): 379-400.

Rientjes T, Haile A T, Fenta A A. 2013. Diurnal rainfall variability over the Upper Blue Nile Basin: A remote sensing based approach. International Journal of Applied Earth Observation and Geoinformation, 21: 311-325.

Sahoo D C, Madhu M G, Bosu S S, et al. 2016. Farming methods impact on soil and water conservation efficiency under tea [Camellia sinensis (L.)] plantation in Nilgiris of South India. International Soil and Water Conservation Research, 4(3): 195198.

Schmidt E, Zemadim B. 2013. Hydrological modelling of sustainable land management interventions in the Mizewa watershed of the Blue Nile basin. In: Rainwater Management for Resilient Livelihoods in Ethiopia: Proceedings of the Nile Basin Development Challenge Science Meeting, Addis Ababa, 9-10 July 2013. NBDC Technical Report 5. Nairobi, Kenya: ILRI, 30 .

Sheldrick B, Wang C. 1993. Particle size distribution. In: Carter M R. Soil Sampling and Methods of Analysis. Boca Raton, Florida, USA: Canadian Society of Soil Science, Lewis Publishers, 499-513.

Sultan D, Tsunekawa A, Haregeweyn N, et al. 2017. Analyzing the runoff response to soil and water conservation measures in a tropical humid Ethiopian highland. Physical Geography, 38(5): 423-447.

Tadesse M, Belay K. 2004. Factors influencing adoption of soil conservation measures in Southern Ethiopia: the case of Gununo area. Journal of Agriculture and Rural Development in the Tropics and Subtropics, 105(1): 49-62.

Taye G, Poesen J, Van Wesemael B, et al. 2013. Effects of land use, slope gradient, and soil and water conservation structures on runoff and soil loss in semi-arid Northern Ethiopia. Physical Geography, 34(3): 236-259.

Tebebu T Y, Steenhuis T S, Dagnew D C, et al. 2015. Improving efficacy of landscape interventions in the (sub) humid Ethiopian highlands by improved understanding of runoff processes. Frontiers in Earth Science, 3: 49. 